ISSN 1112-9867

Available online at http://www.jfas.info

\title{
A GLANCE ON LOVE \& INFIDELITY IN "CAPTIVE" COMPOSED BY FOROOGH FARROKHZAD
}

\author{
H. Bassak, F. S. Bokharaei
}

Associate Professor, Persian Language and Literature Dept, Payame Noor University (PNU), 19395- 4697 Tehran, Iran

Master's Degree Program Student in the Field of Persian Language \& Literature at Islamic Azad University, Iran

Published online: 15 May 2016

\begin{abstract}
Love and amorous relations, infidelity, and disloyalty are inseparable parts of the modern human's life and are considered as social problems in human relations in communities. In conflict of the genders among the people the most conspicuous evidence is "ardent desire for love". Humans get married because of love and their intrinsic need for coexistence and separate from each other due to quench of love thirst resulted from change in attitudes, etc...Love is the sole standing where humans may find a true understanding of themselves and join other humans. Love is both disappointing and comforting at the same time. It is a powerful force that obeys its unique rules and reveals its messages in people's expectations and behavioral patterns. infidelity is defined as the establishment of sexual relations between two individuals from opposite sex outside the family relations that starts with infidelity and its major motivation is enjoyment. Establishing these relations is not possible without resorting to telling lie. Foroogh Farrokhzad as one of the contemporary female poets composed a collection of poems including 44 poems entitled "Captive" in 1952 in which the pain of love and infidelity is felt from every word.
\end{abstract}

Author Correspondence, e-mail: bassak@pnu.ac.ir

doi: http://dx.doi.org/10.4314/jfas.v8i3s.101 
Thus, the present research paper reviews her attitude about these two components -love and infidelity - through analyzing some of her poems in this collection and illustrates a different aspect of these themes. Love is illustrated as a pure spiritual desire that even its memorial gives a fresh life to the lover. She believes that infidelity is offering this pure love incarnated in body to the beloved who does not know anything except physical enjoyment.

Key words: Foroogh, Love, Infidelity, Woman, Man

\section{FORWARD}

Love may be considered as a media by resorting to which man releases himself from loneliness and anxiety. It acts as a powerful force that prevents human from being isolated and conducts him towards perfection accompanied with his beloved. But sometimes, after joining of the beloved, one of the parties in a love relation cuts off his/her relation with his/her beloved due to some reasons and tries to continue his/her relation with another person which is called infidelity in social common law.

\subsection{Research Questions}

We have heard that Forough Farrokhzad is a rebellious and insurgent poet against common people's beliefs and traditions. Your mind will be filled with questions after reading her poem collection "Captive" such as:Is Forough hatred from being captivated by love? Does she prefer infidelity to being faithful to love or infidelity has another meaning for her, and what is the reason that she deems herself unfaithful and sinner?

\subsection{Assumptions:}

The first assumption raised by the common people after hearing Forough's divorce is that she separated from her spouse because she considered herself disloyal and sinner in her poem due to having sexual relations with another man and she got divorce for preventing from infamy and reaching more freedom. The second assumption that expresses a more intellectual attitude is that since her period of life was overwhelmed by patriarchy, Forough deemed free sexual relations by females as an evidence of rebellion against males. The third assumption which may be considered as a new glance on her poems is that the definition of disloyal in Forough's poems has a new meaning for understanding of which we should focuses deeply on her life and her attitude towards love relations.

\subsection{Research Background}


Many books and articles have been written about Forough Farrokhzad's poems. Some considerable examples are as follows:

1. Koopa, Fatemeh, Kahandani, Mohammad Reza, and Gorji, Mostafa, 2010, the Concept of Pain and Suffering in Contemporary Female Poets' Outlook, ScientificResearch Quarterly of Literary Criticism, $3^{\text {rd }}$ year, issue No.9, pp.141-162.

2. Hosseinpour, Ali, Mousavi, Soghra Sadat,2005, Comparative Analysis of Forough's and Sepehri's Poetry from Intellectual and Conceptual Viewpoint, Literary Researches Quarterly, Issues Nos. 9 and 10,pp.75-92. In those articles we find that Forough complains from lack of empathy and compassion and not finding her real beloved one.

\subsection{The Necessity \& Significance of Research}

The present paper tries to illustrate the real and internal character of Forough Farrokhzad through approving or disapproving the assumption to which we have referred before and removing the ambiguities in this regard.

\section{INTRODUCTION}

Humans without consideration to their age, culture, etc... are always in quest of finding real love; the love that fills their existence with enthusiasm of life; all of these people suffer from being suspicious that their beloved may be disloyal to them. They have a specific definition of love and pain of infidelity but how does Forough define them? Do these words have the same meaning in her poem as given by the common people?

\section{FOROUGH FARROKHZAD}

Forough Farrokhzad was born in Tehran on Jan.05, 1934. She fell in love with Parviz Shapoor when she was 16 years old; she married him but their matrimonial life did not last long and they separated each other. The fruit of this marriage was their son named"Kamyar". Her poem collection entitled "Captive" was published when she was 18. Refer to Moradi Koochi,2000 for more information. Forough expresses her objective of composing these poems as follows: My desire is freedom of the Iranian women and their equity of rights with men (Ibid, 13:2000). 


\section{LOVE}

Love may be one of most difficult words to be interpreted because every one gives a definition about it upon his/her own experience; in general, it may be said that Love is the demand for adjoining during an attachment process in direction of individual's perfection and is not limited to specific conditions. The lover and the beloved, both reach each other in one point and unite with each other and become one (Modarres Motlagh,47-49:1996).

\section{INFIDELITY}

Infidelity is a process for cutting off a love relation established between two human beings which develops step by step, involves the emotions, and when the emotional excitements subside, the physical desires are emerged.

\section{FOROUGH AND LOVE}

Antony Gidens and Karen Berdsal in their sociology book introduce "Love relations" as a pure relation; a pure relation based on mutual confidence and independence and the ability to establish relations with each other as independent adults who deserve to make emotional and practical relations and obtain sufficient satisfaction in order to protect their relations. From their points of view, pure relation is the one free of being intervened by culture, tradition, religion, and family .(Gidens,132-40:1999). In the era when Forough lived, in the structure of Iran in that time, the women and men did not enjoy equal social power and personal wealth. The women were defined by marriage in that society and their occupational standing was not considered independent even though they have developed their education. Where culture, tradition, religion, and family status played the essential role, her poetry was the loud cry of words which raised new feminine beliefs and desires; love was not merely desire, mental agony and some expressions about union with the beloved, that is the end of everything. Forough describes love in a simple and deep structure which have a brilliant and pure climax; In her poetry, the lover does not pursue a physical need to be met by his/her beloved but he/she is seeking for a mental tranquilizer which may be achieved even by reminiscence of the beloved; Here, her love is an opening towards new mental horizons. The beloved's eye and eyebrow in her poetry is not merely in its human's frame but it is the color of a deep love that makes it beautiful. John Brad 
Shaw says: The first level of love is lustful instinct and its last stage that is the most perfect one, so called as platonic love, is a godly love that has no relation with body and physical desires and is so idealistic that changes to a myth. (Brad Shaw, 198:2002) and Forough reaches to such love.

\section{FOROUGH \& INFIDELITY}

Forough, in her poetry, illustrates the significance of the pure and free love relation changed in a concern nowadays. The period of Forough's life is the one in which few women express their love and always the men strode the first step. Forough tries to change this role and encourage women to express their love firstly. In her poetry, she sometimes illustrates short-time sexual relation that is quenching the periodical need. This is due to expressing love by woman because if she wants to be a lover, not a beloved, she should redeem for this which is merely a relation empty of love and its termination is certainly by men,i.e., the power to establish relation is still in their hands.

The idealistic attitudes about love, idealistic imagination about the beloved, then, and facing a bitter reality about the beloved establish an ascending and descending process in relations and change the romantic atmosphere in love relation the consequence of which is cold relation that causes the trend to break it for seeking another ideal beloved. This is why she expresses her sensation and emotions frankly and unbelievably calls herself as an infidel because she sells her soul via her body. It annoys her because she has not surrendered her body to love but she has offered her body to the man's lust and this is a sin. From Forough's point of view, this is prostitution, the definition and reality of the word "Infidelity"; from this aspect we enter her world to experience ugliness and beauty with her.

\section{FOROUGH'S POETRY \& LOVE AND INFIDELITY TINT}

Surveying "Captive" poem collection, we feel the warmth of love and bitterness of infidelity by her specific outlook.

$\mathrm{He}$ is the scared away flame of sun / It is useless to run for reaching him/ $\mathrm{He}$ is the blossomed bud of moonlight / On the meadow of the night-stricken of an eye / That summons him to sinful bed /The fragrance of the silent kisses, 
Should be blended with enthusiastic moans / In the long hairs of that enchantress / $\mathrm{He}$ should pour love and lust insanely.

He should drink the wine cups of kisses / From those chanting lips / He should lay his head and rest drunkenly / On the breast of a beauty

Farrokhzad, 16:1970" / Forough calls her beloved as the flame scared away from his origin that should go away; and in indefinite degree of agony, he does not belong only to a body but to all the ones that summon him to their beds and he goes there and drinks the wine of kiss wherever it is and he lays his head on any breast to rest drunkenly. In spite of this evident infidelity, Forough calls her heart sinner and infidel because it has mistakenly heard the summons of love once. However, Forough does not allow herself to blame the beloved; therefore, she expresses her feelings in the veil of the most beautiful words. She calls him a moonlight that shines on everyone and touches warmly their bodies at nights. She calls her beloved as the sunshine and herself as the mud-land on which nothing to be grown and fertilized so that she will have no need for the radiation of the sunshine. She calls her heart as a sinful rocky terrain because it has remained lover for a long time. Her heart is the lover of the one who showers rain of compassion to everyone except her.

Your love is as the moonlight / Shone unconsciously on a mud-land / It is as a compassion rain / howered on the rocked terrain of a sinner heart / I am eternal darkness and corruption / You are the brilliant sunshine of hope / On my heart, you the blissful light / Have not shone for a long time (Ibid,38:1970)

When the beloved comes to her full of desire and drunkenness, he wants a fruit from this love and he knows nothing except her body. / I stared at his both eyes and he said / We should harvest from love.

A shadow bent over a shadow.(Ibid.30:1970).

He sleeps with her and quench his thirst for her body while he demands her passionate body to be coquettish so that his body be filled with lust in order to gratify his lust but this is not the love quested by the woman. She wants love, the pure love from which both soul and body are drunk; the body should be considered as a priceless excuse, but certainly, her beloved is unfamiliar with the beautiful world of love. He is as a passerby who crosses this domain with his body. 
He demands the wine of kiss from me / What should I reply to my hopeful heart? / He thinks of pleasure and is ignorant / that I am seeking for eternal pleasure / I want pure love from him / So that I sacrifice for it my existence / She demands a fiery body / To burn his anxiety / He says to me, O, embrace me warmly / and drunken me with your coquetry because I am insane / I say to him, O, the stranger, pass me, I am stranger to you.(Ibid.40:1970).

Nowadays, some people who have not understood the meaning of Forough's zealous love , recognize stranger as any man who passes a course and she surrenders herself to him. May we consider that she is in quest of freedom, releasing passion, and infidelity, while, she deems love as defined above. If we pay attention to this matter, we will see that she complains from the man who is captivated by the lustful desires of his body; when the beloved has gone away full of this pleasure, Forough calls him to return. She speaks of the subjects which are comprehensible for him. He merely knows body; therefore, she asks him to remember her hot lips and body and to come back to her and this is why some people consider her mistakenly as body-oriented.

Remember that woman / That insane women who slept / One night on your chest, drunken with love and coquetry / Shivered on her thirty lips, passion / Laughed at her escaping glance, demand / Her thirsty lips kissed your hot lips / She retold the tales of your eagerness through her look (Ibid,44:1970).

In the poem entitled "Farewell" she makes a confession that is painful for women. She confesses that she has fallen in love once and has not remembered that the men in her land can not be beloved and understand the love flowing in a lover women's heart. They have learned that merely they are deserved to fall in love. She should bid farewell to her husband who is her beloved while her heart is full of grievance, maybe, the stain of the sin to be a lover that should be washed out.

I take my frenzied and mad heart / To wash it out of sin in that far place / To wash it out of the stain of love.(Ibid.,54:1970).

His beloved man comes back but how, He has come to lock her lips with silence and to throw her in the cage of silence but this woman does not want such a love anymore; the love that is not to blaze, to be silent, and does not compose any poem; she does not want such a love even if it is the promised paradise. If revealing the secret of heart is shameful, 
she does not feel ashamed of scandal; she accepts this sin and wants to reside in the deepest point of hell.

Do not say that your poem is shameful, too shameful / Do you know that this cage is very tight, too tight / for those frenzied lovers / Do not say that your poem is full of sin / Give me a cup of this shame and sin / Paradise, nymph, and water from the fountain in paradise all be of yours / Reside me in the deepest point of hell.(Ibid,75:1970)

In the poem entitled "the Bored", we see that the man of her land is cruel to the woman who loves him and considers her as a simpleton and sometimes deems her a prostitute because if the Iranian woman reveals the secret of her love, she is convicted be called as simple-minded.

I no longer sacrifice my pride to his love foolishly / Maybe, if I ignore him / I will find my lost happiness and mirth / The one who made me happy and drunkard / One who gave me hope and enjoyment / Wherever he spoke in a gathering,/ He said unhesitatingly "She was a vulgar simpleton”.(Ibid,108:1970)

How does this woman express her agony. She has committed infidelity herself. Since the moment that she surrenders herself to this man for finding real love, she became infidel and tightened the chain of captivity to her feet.

Undoubtedly, no one did not annoy herself as did I / I myself caused to suffer this agony./ No way is for the one who commits this sin / My foot is in chain and I moan that / I have no familiarity with the chain loop (Ibid, 129:1349)

Forough runs out of patience from so much suffering and begs for help from the creator of love. She says about the first wrong doing made by her heart that he surrendered herself to a man whom she thought to be her real love. The love that is not only the lustful desires and the one that ascends soul to the heaven; but it committed a sin and betrayed to the heart and soul gifted by God. She who finds her body stained with her beloved's lust, hates him and begs God to give her a new body and the love in which she understands the pure nature of the Truth and ascends her to the rank of the angels; If God does not assist her, she will commit sin again, the sin to be loyal to the man who knows only physical desires; ultimately, this is the peak of self-sacrificing.

Only you are aware and know / The secrets of the Original Sin / Only you are able to give / To my soul, the original pureness / O, My God, how can I tell you / That I am tired and 
hatred of my body? Every night I beg you to give me another body / Take out of my brilliant eyes / The enthusiasm to run towards others / O, my God, do me a favor / Learn my new body to escape away from the sparks of others' eyes./ Gift me a love that changes me / And makes me as the angles of your paradise (Farrokhzad,142:1970).

\section{CONCLUSION}

Whatever we find from the poems of Forough Farrokhzad's "Captive", it may be said that love in her poetry is a pure spiritual desire in which human being is influenced merely by his/her own affections and morale and does not withhold from sacrificing his/her life for the beloved. The beloved whose reminiscence refreshes human being and the ideals of human's mind are materialized in him/her. The beloved under his/her shadow of whom human being can be rescued of life sufferings in hope of uniting with him/her; and in the light of his/her security, can terminate his/her internal controversies and pave the way towards perfection. Sometimes, Forough deems infidelity as sexual intercourse with an individual from the opposite sex beyond the family framework and with the motivation of hedonism and sometimes in a deeper outlook, she calls herself as infidel.

This is a definition different from the common ones. She considers love as a sacred light that if radiates on the non-real beloved, i.e., the beloved that admires only body not soul and the pure love for whom uniting means physical union and there is no spiritual attraction in it, this is infidelity because such a beloved is stranger with the essence of love and has not found in himself the gem gifted to him by God in the first day. He ruins whatever of the enthusiasm of love is embedded in his opposite sex in lovemaking and makes from her a useless earthly body; therefore, she should not accompany such a beloved because it is infidelity and whoever does such an action is undoubtedly a sinner. In "Captive", Forough specifically asks her fellow women not to surrender the spirit of love in the frame of body to the strangers and when they find the gem of real love, a love accompanied with body and soul, they captivate themselves of such love; there is no love loftier and more sacred than this one. 


\section{REFERENCES}

1. Brad Shaw, John, (2002), Love Creation, Translated by Javad Shafei Moghaddam and Nayyereh Ijadi, Tehran: Peykan Publication Cener, $1^{\text {st }}$ Edition.

2. Farrokhzad, Forough, (1970), Captive, the forward written by Shojaoddin Shafa, Tehran: Amir Kabir Publication Cener, $6^{\text {th }}$ Edition.

3. Gidenez, Anthony and Berdsal, Caren, (2007), Sociology, Translated by Hassan Chavooshian, Tehran, Ney Publication Center, $1^{\text {st }}$ Edition.

4. Moradi Koochi, Shahnaz (2000), Forough Farrokhzad' Biography and Bibliography, Tehran: Ghatreh Publication Center, $1^{\text {st }}$ Edition.

5. Modarres Motlagh, Mohammad Ali,(1996), An Introduction to Love Essence, Tehran, Mofid Publication Center, $1^{\text {st }}$ Edition.

\section{How to cite this article:}

Bassak H, Bokharaei F S. A glance on love \& infidelity in "captive" composed by foroogh farrokhzad. J. Fundam. Appl. Sci., 2016, 8(3S), 1049-1058. 